\title{
The risk factors profile of coronary heart disease in dyslipidemic patients : Results from a survey in $\mathbf{1 3}$ cities in Indonesia
}

\author{
Harmani Kalim, Rinambaan Willem Mamentu Kaligis
}

\begin{abstract}
Abstrak
Insidens penyakit jantung koroner (PJK) telah mengalami kenaikan yang bermakna dari tahun ke tahun dan menunjukkan angka kematian yang tinggi di Indoneisa. Salah satu faktor risiko PJK yang penting adalah kadar lipid yang tidak normal atau dislipidemia, walaupun terdapat faktor risiko lain di negara-negara Barat. Data mengenai faktor risiko PJK di Indonesia sangat terbatas dan biasanya hanya terdapat di rumah sakit. Penelitian ini bertujuan untuk menganalisis profil risiko PJK pada pasien dislipidemia yang datang di praktek-praktek dokter di Indonesia. Penelitian ini merupakan survei potong-lintang melalui dokter-dokter praktek di 13 kota yang biasa mengobati pasien dislipidemia. Mayoritas pasien dislipidemia dalam praktek adalah kelompok risiko tinggi untuk PJK. Umur, HDL-C rendah dan hipertensi adalah faktor-faktor risiko umum yang terbanyak. Prevalensi faktor-faktor risiko dan proporsi penderita dislipidemia yang masuk golongan risiko tinggi dalam penelitian ini sebanding dengan hasil penelitian L-TAP Amerika Serikat. (Med J Indones 2001; 10: 42-7)
\end{abstract}

\begin{abstract}
The incidence of coronary heart disease (CHD) has significantly increased and has been associated to the high mortality rate in Indonesia. One important CHD risk is the abnormal lipid profile or dyslipidemia, but there are other risk factors that has been associated with CHD in Western population. In Indonesia, data on CHD risk factors are very limited and usually only available as hospital-based data. The aim of this study is to analyze the CHD risk profile in the private clinical practice setting and to determine the factors affecting CHD in dyslipidemic patients in Indonesia. This study is a cross-sectional survey which targeted physicians in 13 cities in Indonesia who regularly treat patients with dyslipidemia. The majority of dyslipidemic patients in clinical practice setting was the CHD high-risk group. Age, low HDL-C and hypertension were the most common risk factors. The prevalence of the risk factors and the proportion of dyslipidemic patients which belongs to the high risk group were comparable to the result of US (L-TAP) study. (Med J Indones 2001; 10: 42-7)
\end{abstract}

Keywords : Coronary Heart Disease, risk factors, dyslipidemia, clinical practice

Cardiovascular disease has been the leading cause of death in many countries, including Indonesia. Data from the Indonesian National Household Health Survey has indicated that deaths due to cardiovascular disease has increased from $9.7 \%$ in SKRT 1986 to $18.9 \%$ in SKRT 1995. ${ }^{1}$ Through this number, cardiovascular disease was placed as the highest cause of death in Indonesia.

Clinical and epidemiological studies including the Helsinki Heart Study ${ }^{2}$, Framingham Study ${ }^{3}$, Lipid Research Clinics Coronary Prevention Trial ${ }^{4}$, and Multiple Risk Factor Intervention Trial ${ }^{5}$ clearly established the link between dyslipidemia and coronary heart disease (CHD). High blood cholesterol,

Department of Cardiology, Faculty of Medicine University of Indonesia/ "Harapan Kita" Hospital /National Cardiac Center, Jakarta, Indonesia especially low-density-lipoprotein cholesterol (LDLC), increases risks for CHD while lowering LDL-C reduces such risks. Previous studies for primary and secondary preventions with statins have also confirmed that lowering LDL-C level in dyslipidemic patients would be beneficial in reducing CHD risks. ${ }^{6,7}$ For these reasons, the United States National Cholesterol Education Program (NCEP) has issued treatment guidelines that identified LDL$\mathrm{C}$ as a causative factor for CHD and as the target for lipid-lowering therapy. ${ }^{8}$

Considering the dyslipidemic patients, it should be noted that patients who came to the private clinical practice might have different risk profile than general population or hospitalized patients. However, data of CHD risks in clinical practice setting is not available. Those patients are important targets for primary and secondary CHD prevention. Therefore, it is important to know the CHD risk profile in dyslipidemic patients. 


\section{METHODS}

\section{Study Design}

The study was an epidemiological study using cross sectional design in 13 cities in Indonesia (Medan, Pakanbaru, Jakarta, Bogor, Bandung, Semarang, Solo, Yogyakarta, Surabaya, Malang, Denpasar, Ujung Pandang and Manado) which targeted physicians who regularly treated patients with dyslipidemia. They were asked to answer questions regarding demographic information, area of speciality and years in practice and selected questions to assess awareness of NCEP guidelines and the LDL-C levels (in $\mathrm{mg} / \mathrm{dL}$ ) at which they start therapy.

\section{Inclusion and exclusion criteria}

Primary dyslipidemic patients with 20 years of age or more and willing to participate in the survey were eligible for the study. The LDL-C level should be $\geq 160 \mathrm{mg} / \mathrm{dL}$. Patients who had a major trauma, surgery that required anesthesia, or myocardial infarction within the 12 weeks prior to enrollment were excluded, as well as those who had an acute infection that required current antibiotic therapy or a recent or abrupt change in their usual diet within the preceding month. Women who were pregnant, breast-feeding, or $\leq 6$ months post partum were also excluded.

\section{Lipid profile determination}

The lipid profile information consisted of serum total cholesterol, LDL-cholesterol, HDL-cholesterol, and triglycerides. Baseline data were used to establish the diagnosis of dyslipidemia and initiation of the treatment. The lipid profile after treatment was the lipid concentration after a minimum of 3-month treatment. Blood samples were taken from all patients and sent to Prodia Laboratory to be evaluated.

Total cholesterol, HDL-C and triglyceride serum levels were determined by chod-pap enzymatic immuno-assay method using automatic photometer Hitachi equipment. LDL-C was calculated based on Friedewalds formula :

LDL-C $=$ Total cholesterol - HDL-C - Triglyceride/ 4

\section{Risk factors assessment}

Data on risk factors other than dyslipidemia including age, family history, smoking, hypertension, low
HDL-C and diabetes mellitus were collected using standardized CHD risk assessment questionaire for each patient. Age risk factor was defined as $\geq 45$ years for male and $\geq 55$ years for female. Family history was considered positive if the patient's father or brother died of CHD below 55 years old, and/or mother or sister died of CHD below 65 years old. Smoking was defined as current smoking habit, while hypertension was indicated as blood pressure $\geq 140 / 90 \mathrm{mmHg}$ or on antihypertensive medication. Low HDL-C level was $<35 \mathrm{mg} / \mathrm{dL}$ and diabetes mellitus was defined as previous history of diabetes mellitus or under antidiabetic medications.

Risk factors were determined for each patients, and the patient was categorized in one of the three risk categories : low-risk group, high-risk group and CHD patients, based on the sum of the risk factor(s). Patients without CHD and had fewer than 2 risk factors other than dyslipidemia were categorized as low-risk group, while patients without CHD with 2 or more risk factors other than dyslipidemia were categorized as high-risk group. CHD patients were those who have clinical manifestations of $\mathrm{CHD}$, i.e. : angina pectoris, history of myocardial infarction and surgical or non surgical intervention for CHD.

\section{Data analysis}

Descriptive analysis was developed for the risk categories, as percentage of patients in each risk group. Risk factors were compared among the risk groups as percentage of each risk factor in each risk group. The number of risk factors in every risk group were also compared. Data were analyzed using SPSS ver 7.5 software.

\section{RESULT}

From February 1, 1999 to July 31, 1999, 188 out of 500 invited physicians have agreed to participate in this study. About 10 consecutive dyslipidemic patients were enrolled by each physician. Among the 188 physicians, the highest number were general practitioners $(67 \%)$ while internists accounted for $15 \%$ and only $5 \%$ cardiologist were enrolled. Their mean years of practice was $24 \pm 9$ years.

There were 1633 case report forms obtained with complete lipid profile which had baseline LDL-C level of $>160 \mathrm{mg} / \mathrm{dL}$. Since the data of demogra- 
phics and treatments are incomplete, 213 forms were excluded from the analysis.

\section{Patients demographics and lipid profile at entry}

The majority of patients was in the high-risk group $(66.1 \%)$, and men were more predominant than women $(58.4 \%$ vs $41.6 \%)$. Oldest subject in the CHD patients and longest in the low-risk group. The means ages (SD) of patients in the low risk high risk and CHD groups were 43.1 (9.6) ; 52.4 (10.1) and 54.3 (11.5) years, respectively. It was clearly shown that the mean of LDL-C was high and was not significantly different among the three risk groups. Mean LDL-C level was highest in CHD patients $(198 \pm 47 \mathrm{mg} / \mathrm{dL})$ but lowest in highrisk group patients $(187 \pm 46 \mathrm{mg} / \mathrm{dL})$. Similarly, mean total cholesterol and mean trigliceride were high and were not significantly different among risk groups. (Tabel 1).

The updated Adult Treatment Panel (ATP II) report of the National Cholesterol Education Program (NCEP) has reaffirmed LDL-C as the primary target for lipid-lowering therapy for CHD primary and secondary prevention. For primary prevention, drug treatment should be considered for an adult patient who despite dietary therapy, has an LDL cholesterol level of (1) $190 \mathrm{mg} / \mathrm{dL}$ or greater in patients with $<2$ other CHD risk factors, or (2) 160 $\mathrm{mg} / \mathrm{dL}$ or greater in patients with less than two other CHD risk factors. The goals of this therapy are to lower LDL cholesterol until less than 160 $\mathrm{mg} / \mathrm{dL}$, or less than $130 \mathrm{mg} / \mathrm{dL}$ if two other risk factors are present. Our study has shown that the means of LDL-C levels for patients without CHD were above the levels for initiation of drug therapy set by US National Cholesterol Education Program (NCEP), i.e. $192 \mathrm{mg} / \mathrm{dL}$ for low risk group (patients with less than two 2 other risk factors) and 187 $\mathrm{mg} / \mathrm{dL}$ for high risk group (patients with two or more other risk factors). CHD patients in our study had LDL-C level (mean : $189 \mathrm{mg} / \mathrm{dL}$ ) beyond the level at which drug treatment should be started (130 $\mathrm{mg} / \mathrm{dL}$ ) as suggested by NCEP guideline. For secondary prevention this guideline stated that, the goal of therapy is an LDL cholesterol level of 100 $\mathrm{mg} / \mathrm{dL}$ or lower. Drug therapy is generally indicated in patients with established CHD or other atherosclerosic disease if LDL cholesterol levels are $130 \mathrm{mg} / \mathrm{dL}$ or more after maximal dietary therapy. If the level is in the range of 100 to 129 $\mathrm{mg} / \mathrm{dL}$, clinical judgment that weights potential benefit, possible side effects, and costs must be considered in the decision for drug therapy.

\section{Risk profile}

The most frequent risk factor found in our study population was age (49.9\%). However, in the lowrisk group, low-HLDL-C was the highest risk factor (21.1\%), while among CHD patients, age was the second highest risk factor after hypertension (67.8\% and $72.2 \%$, respectively). Age was the most common risk factor in high-risk group, but the percentage was less than CHD patients. A positive family history significantly increased the risk of CHD; the percentage was 2.6 fold in CHD patients compare to the high-risk group. The prevalence of all risk factors were highest in dyslipidemic patients with CHD. (Tabel 2)

In low-risk group patients the majority of patients $(73.5 \%)$ had only one risk factor, whereas in the

Tabel 1. Patients demographics and profile

\begin{tabular}{lcccc}
\hline \multicolumn{1}{c}{$\mathrm{N}$} & Low Risk & High Risk & CHD Patients & Total \\
& $366(25.8 \%)$ & $939(66.1 \%)$ & $115(8.1 \%)$ & $1420(100 \%)$ \\
\hline Mean Age (yrs) & $43.1 \pm 9.6$ & $52.4 \pm 10.1$ & $54.3 \pm 11.5$ & $50.3 \pm 0.9$ \\
Sex & $\mathrm{M}: 51.3 \%$ & $\mathrm{M}: 61.0 \%$ & $\mathrm{M}: 59.6 \%$ & $\mathrm{M}: 58.4 \%$ \\
& $\mathrm{~F}: 48.7 \%$ & $\mathrm{~F}: 39.0 \%$ & $\mathrm{~F}: 40.4 \%$ & $\mathrm{~F}: 41.6 \%$ \\
BMI $\left(\mathrm{kg} / \mathrm{m}^{2}\right)$ & $23.3 \pm 2.8$ & $25.2 \pm 3.0$ & $25.1 \pm 2.6$ & $24.8 \pm 3.1$ \\
Total chol. $(\mathrm{mg} / \mathrm{dL})$ & $271 \pm 54$ & $267 \pm 47$ & $270 \pm 58$ & $268 \pm 50$ \\
LDL chol. $(\mathrm{mg} / \mathrm{dL})$ & $192 \pm 47$ & $187 \pm 46$ & $198 \pm 58$ & $189 \pm 47$ \\
HDL chol. $(\mathrm{mg} / \mathrm{dL})$ & $49 \pm 34$ & $41 \pm 20$ & $40 \pm 14.7$ & $43 \pm 24$ \\
Triglyceride $(\mathrm{mg} / \mathrm{dL})$ & $207 \pm 98$ & $232 \pm 105$ & $227 \pm 9$ & $226 \pm 104$ \\
\hline
\end{tabular}


Tabel 2. Distribution and number of risk factors among patient groups

\begin{tabular}{lcccc}
\hline \multicolumn{1}{c}{$\mathrm{N}$} & $\begin{array}{c}\text { Low Risk } \\
366(25.8 \%)\end{array}$ & $\begin{array}{c}\text { High Risk } \\
939(66.1 \%)\end{array}$ & $\begin{array}{c}\text { CHD Patients } \\
115(8.1 \%)\end{array}$ & $\begin{array}{c}\text { Total } \\
1420(100 \%)\end{array}$ \\
\hline Age & $16.1 \%$ & $60.9 \%$ & $67.8 \%$ & $49.9 \%$ \\
Family History & $1.1 \%$ & $15.5 \%$ & $40.9 \%$ & $13.9 \%$ \\
Smoking & $6.3 \%$ & $35.4 \%$ & $46.1 \%$ & $28.7 \%$ \\
Hypertension & $2.2 \%$ & $44.6 \%$ & $72.2 \%$ & $35.9 \%$ \\
Low HDL-C & $21.1 \%$ & $39.3 \%$ & $44.3 \%$ & $35.0 \%$ \\
Diabetes & $0.8 \%$ & $16.8 \%$ & $22.6 \%$ & $13.2 \%$ \\
0 & $97(26.5 \%)$ & & & $97(6.8 \%)$ \\
1 & $269(73.5 \%)$ & & $5(4.3 \%)$ & $274(19.3 \%$ \\
2 & & $372(39.6 \%)$ & $17(14.8 \%)$ & $389(27.4 \%)$ \\
3 & & $284(30.2 \%)$ & $29(25.2 \%)$ & $313(22.0 \%)$ \\
4 & & $180(19.2 \%)$ & $30(26.1 \%)$ & $210(14.8 \%)$ \\
5 & & $80(8.5 \%)$ & $22(19.1 \%)$ & $102(7.2 \%)$ \\
\hline
\end{tabular}

Tabel 3. Patients demographics and risk factors of US L-TAP survey vs Indonesia L-TAP survey

\begin{tabular}{lcccccccc}
\hline & \multicolumn{2}{c}{ Low Risk } & \multicolumn{2}{c}{ High Risk } & \multicolumn{2}{c}{ CHD Patients } & \multicolumn{2}{c}{ Total } \\
\cline { 2 - 9 } & USA & INA & USA & INA & USA & INA & USA & INA \\
& $23 \%$ & $26 \%$ & $47 \%$ & $66 \%$ & $30 \%$ & $8 \%$ & $4888(100 \%)$ & $1420(100 \%)$ \\
\hline Age (yrs) & $59 \%$ & $16 \%$ & $92 \%$ & $61 \%$ & $95 \%$ & $68 \%$ & $85 \%$ & $50 \%$ \\
Male (\%) & 39 & 51 & 47 & 61 & 65 & 59.6 & 50 & 60 \\
BMI (kg/m ${ }^{2}$ ) & 28 & 23 & 29 & 25 & 29 & 25 & 29 & 25 \\
Family History (\%) & 15 & 1 & 41 & 16 & 46 & 41 & 35 & 14 \\
Smoking (\%) & 6 & 6 & 19 & 35 & 13 & 46 & 14 & 29 \\
Hypertension (\%) & 16 & 2 & 70 & 45 & 63 & 72 & 55 & 36 \\
Low HDL-C (\%) & 3 & 21 & 22 & 39 & 22 & 44 & 17 & 35 \\
DM (\%) & 2 & 0.8 & 21 & 16.8 & 24 & 22.6 & 17 & 13.2 \\
\hline
\end{tabular}

high-risk group, the majority of patients $(39.2 \%)$ had two risk factors. Among CHD patients, most patients had 3 or 4 risk factors.

Among the female patients, the majority of patients were in the 40-59 years age group (61\% of 518 female patients). It was similar to the male patients which accounted for $65.5 \%$ of 743 male patients. The high-risk patients were also predominated by the 40-59 years age group, which were $65 \%$ female and $74.7 \%$ male patients. But the highest proportion of high-risk patients was in the 60-79 years age group in male patients $(78.7 \%)$. (Tabel 3$)$

\section{DISCUSSION}

Atherosclerosis is a disease process that begins early in life and progresses without symptoms. More than half of all myocardial infarctions occur in persons without known $\mathrm{CHD}$ and at least one quarter of first infarction are fatal. Fourty eight of men and $64 \%$ of women who die suddenly of acute myocardial infarction had no prior clinical evidence of CHD. (AHA Heart \& Stroke Facts 1998 ). These are some reasons why it is important to carry out primary prevention by identifying CHD risk factors and recognizing who are at high risk for such disease.

Our current study has shown that most of Indonesian dyslipidemic patients visiting private clinical practices were prone to CHD as indicated by the high percentage of high-risk group patients (Tabel 1.)

The US Lipid Assessment Project (US L-TAP) study in $1996^{9}$ involving 4888 patients resulted in $23 \%$ lowrisk patients, $47 \%$ high-risk patients, and 30\% CHD patients. Although this study showed a high proportion of high-risk patients, our CHD patients were still much lower compared to USL-TAP study. This study involved more male patients than US study. 
Among the risk factors, age was prominent since it was found in almost half of the patients $(49.9 \%)$. But this number is much lower compared to the US L-TAP study. The age-risk factor in US L-TAP study was accounted for $59 \%$ low-risk patients, 92 $\%$ high-risk patients and $95 \%$ CHD patients. This difference implies that our high-risk patients are much younger from US patients and our patients are earlier being exposed to CHD risk factors.

Other important differences were the low HDL-C level, which has shown to be higher in our study compared to US study; current smoking habit that was found more frequent in our patients; and a positive family history, which was found more than in US study.

The proportion of hypertensive and diabetic patients seemed to be quite similar between the two studies. Hypertension was more frequent in highrisk patients in US study, but in our study, it was more frequent in $\mathrm{CHD}$ patients. Diabetic risk factors were highest in $\mathrm{CHD}$ patients in both studies.

Results from the Multiple Risk Factor Intervention Trial (MRFIT) has shown that among 316.099 white men, blood cholesterol, cigarette smoking, diastolic blood pressure, and age were significantly associated with CHD mortality, whereas age, diastolic blood pressure and cigarette smoking were associated with total mortality. ${ }^{10}$

Other report, i.e. the Prospective Cardiovascular Münster (PROCAM) longitudinal study has shown that from their male participants ages 40 to 65 years, hypertension, diabetes mellitus, and hyperlipidemia are independent risk factors for CHD. Hyperlipidemia was a more significant risk factor for CHD than hypertension and diabetic mellitus. ${ }^{11}$

Our study has shown that $40.9 \%$ of CHD patients had a positive family history while the prevalence of this risk factor in low risk and high risk group were $1.1 \%$ and $15.5 \%$ respectively. This finding supported the hypothesis that a family history positive for CHD will increase the risk of CHD. A match-paired study in 106 hospital cases and 106 hospital control has shown that the odds ratio of patients suffering from CHD with a positive family history was 4.95 (95 \% CI - 1.27-19.28) compared to those without a positive family history. ${ }^{12}$

Although some major risk factors has shown to be relatively similar in indicating relationships with CHD and CHD mortality; the pattern was quite different in various countries. Signifcant association was not found between CHD mortality and age in Croatia and Japan, cholesterol in Croatia and Japan, systolic blood pressure in Serbia and Greece, and cigarette-smoking in Netherlands, Croatia, Serbia and Greece. ${ }^{13}$

\section{CONCLUSION}

Our study shows that the majority of dyslipidemic patients in clinical practice setting belonged to the high-risk group. In addition, the majority of these patients $(75 \%)$ had 2 or more other risk factors and quite many of them ( $46 \%$ ) had 3 or more other risk factors in addition to dislipidemia. Overall, age, low HDL-C and hypertension were the most common risk factors. Positive family history, smoking habit and diabetes mellitus were also found to be the highest in CHD patients. The prevalence of the risk factors was comparable to the result of US L-TAP study and other previous studies.

\section{ACKNOWLEDGEMENTS}

The authors wish to thank all the physicians in 13 cities who have participated in this study. Without their supports this study would not possible to carry out.

\section{REFERENCE}

1. Ministry of Health Republic of Indonesia. National Health Household Survey 1995, Jakarta.

2. Frick MH, Elo O, Haapa K, Heinonen OP, Heinsalmi P, Hello P, et al. Helsinki Heart Study : Primary prevention trial with gemfibrozil in midle-aged men with dyslipidemia. N Eng J Med 1987; 317:1237-45.

3. Castelli WP, Garrison RJ, Wilson PWF, Abbot RD, Kalousdian S, Kannel WB. Incidence of coronary heart disease and lipoprotein cholesterol levels. The Framingham Study. JAMA 1986;256:2835-8.

4. Lipid Research Clinics Program. The Lipid Research Clinics Coronary Primary Prevention Trial Results, I : reduction in the incidence of coronary heart disease JAMA 1984; 251:351-64.

5. Neaton JD, Blackburn H, Jacobs D, Kuller L, Lee DJ, Sherwin R, et al. Serum cholesterol level and mortality 
findings for men screened in the Multiple Risk Factor Intervention Trial. Arch Intern Med 1992; 152 : 1490-1500

6. Shepherd J, Cobbe SM, Ford I, Isles CG, Lorimer AR, MacFarlane PW, et al. For the West of Scotland Coronary Prevention Study Group. Prevention of coronary heart disease with pravastatin in men with hypercholesterolemia. N Engl J Med 1995;333:1301-7.

7. Sacks FM, Pfeffer MA, Moye LA, Rouleau JL, Rutherford JD, Cole TG, et al. The effect of pravastatin on coronary events after myocardial infarction in patients with average cholesterol levels. Cholesterol and Recurrent Events Trial Investigators. N Engl J Med 1996;335:1001-9.

8. National Cholesterol Education Program in Adults. Summary of the Second Report on the National Cholesterol Education Program Expert Panel on Detection, Evaluation, and Treatment of High Blood Cholesterol in Adults (Adult Treatment Panel II). JAMA : 1993;3015-23.

9. Pearson TA, Laurora I, Chu H, Kafonek S. The Lipid Treatment Assessment Project (L-TAP). A multicenter survey to evaluate the percentages of dyslipidemia patients receiving lipid-lowering therapy and achieving low-density lipoprotein cholesterol goals. Arch Intern Med 2000;160: 459-67.
10. Neaton JD, Wentworth D. Serum cholesterol, blood cholesterol, cigarette smoking, and death from coronary heart disease. Overall findings and differences by age for 316.099 white men. Multiple Risk Factor Intervention Trial Research Group. Arch Intern Med 1992;152:56-64.

11. Assman G, Schulte H. The Prospective Cardiovascular Münster (PROCAM) study ; prevalence of hyperlipidemia in persons with hypertension and/or diabetes mellitus and the relationship to coronary heart disease. Am Heart J 1988; 116 (6 Pt2); 1713-24.

12. Castro Beiras A, Muñiz J, Fernández Fuertes I, ladoCanosa A, Juane R, Pasalodos-Pita J, et al. Family history as an independent risk factor for ischemic heart disease in a low incidence area (Galicia, Spain). Eur Heart J 1993; 14: 1445-50.

13. Menotti A, Keys A, Blackburn H, Kromhout D, Karvonen $\mathrm{M}$, Nissinen $\mathrm{A}$, et al. Comparison of multivariate predictive power of major risk factors for coronary heart diseases in different countries; results from eight nations of the Seven Countries Study, 25-year follow-up. J Cardiovasc Risk 1996; 3:69-75. 